No. 6(63), 2019, pp. 233-246

https://doi.org/10.12797/Politeja.16.2019.63.16

Jakub JUSKO iD

Masaryk University

jakub.jusko@fss.muni.cz

\title{
WELFARE, BUT ONLY FOR US?
}

\section{RANDOMIZED SURVEY EXPERIMENT ON WELFARE CHAUVINISM CONDUCTED ON STUDENTS IN BRNO}

ABSTRACT The immigrants' rights to welfare benefits have been heavily discussed in European Union member states recently. This study focuses on general opposition to those rights, welfare chauvinism, and its potential existence in the country with essentially no immigration issues - the Czech Republic. Using a survey experiment on students of Masaryk University in Brno, a change in the attitudes towards the child benefits (as one aspect of social benefits) was observed right after they were reminded that also immigrants from other countries have access to those benefits. The effect of persuasive argument was stronger in the case of Bulgarian rather than German immigrants, which could imply Czechs perceive Germans more positively than they do Bulgarians, and they behave less chauvinistically towards them in comparison to citizens of Bulgaria.

Key words: welfare chauvinism, welfare benefits, survey experiment, Czech Republic 


\section{INTRODUCTION}

The concept of the welfare state has become one of the most characteristic features of contemporary European society. This phenomenon has thus been studied from different perspectives to understand what it is and what it means for the citizens of the countries and the state itself. One aspect has been the subject of academic interest in recent years in relation to the welfare state and social benefits: welfare chauvinism, a term which refers to a general unwillingness of native population to share welfare benefits with immigrants, and their general opposition to cross-border welfare rights (whether inside or outside of an EU context). ${ }^{1}$ The existence of welfare chauvinism has been confirmed in several studies analyzing the situation in Nordic and Western countries. ${ }^{2}$ Not much attention has been paid to Central Europe. This paper aims to fill this gap, focusing on the Czech Republic, a country in a particular situation, as it essentially has no immigration issues.

Welfare chauvinism has been examined by scholars from different perspectives, and the academic literature provides several explanations for the existence of this phenomenon. First, welfare chauvinism is a result of cultural distance and differences between immigrants and a native population. If values and lifestyles of "newcomers" are perceived by the natives as threatening to their own values, the support for redistributive welfare policies is undermined. ${ }^{3}$ Second, welfare chauvinism refers to competition on the labor market between natives and immigrants. The necessity to compete and the personal interests of natives can negatively affect attitudes towards immigrants, whose presence on the market typically affects wages and working conditions of people. ${ }^{4}$ Third and finally, cultural and economic threats to the native population also result from the position of immigrants within the welfare system itself - for example their over-representation in receiving welfare benefits. ${ }^{5}$ This can be one of the reasons why natives perceive sharing

H. Kitschelt, The Radical Right in Western Europe: A Comparative Analysis, Ann Arbor 1997, p. 346; see also: H. Kitschelt, "Growth and Persistence of the Radical right in Postindustrial Democracies: Advances and Challenges in Comparative Research", West European Politics, vol. 30, no. 5 (2007), pp. 1176-1206.

2 A-H. Bay, H. Finseraas, A. W. Pedersen, "Welfare Nationalism and Popular Support for Raising the Child Allowance: Evidence from a Norwegian Survey Experiment”, Scandinavian Political Studies, vol. 39, no. 4 (2016), pp. 482-494; W. De Koster, P. Achterberg, J. Van der Waal, “The New Right and the Welfare State: The Electoral Relevance of Welfare Chauvinism and Welfare Populism in the Netherlands", International Political Science Review, vol. 34, no. 1 (2012), pp. 3-20; F. Hjorth, "Who Benefits? Welfare Chauvinism and National Stereotypes", European Union Politics, vol. 17, no. 1 (2016), pp. 3-24.

3 J. Citrin, D-P. Green, C. Muste, C. Wong, "Public Opinion toward Immigration Reform: The Role of Economic Motivations”, The Journal of Politics, vol. 59, no. 3 (1997), pp. 858-881.

4 See: F. Hjorth, "Who Benefits? Welfare Chauvinism and National Stereotypes", European Union Politics, vol. 17, no. 1 (2016), pp. 3-24.

5 See: A. Alesina, E. Glaeser, Fighting Poverty in the US and Europe: A World of Difference, New York 2004. 
benefits in a negative way. There might also be a general feeling of illegitimacy, since newly coming immigrants have not paid prior contributions to the national social insurance system, nor have they contributed enough to the society, yet they receive benefits. ${ }^{6}$

Theoretical assumptions about the existence of welfare chauvinism has been recently backed by two experimental studies from the Nordic region. A study by Hjort from 2016 set out to analyze determinants of popular opposition to the idea of sharing welfare benefits with immigrants, more specifically the child allowance. In order to test the effect of stereotypes on welfare chauvinism, Hjort implemented randomized cues about beneficiary characteristics in a large-scale survey among Swedish voters regarding attitudes towards cross-border welfare rights. Those cues were related to the citizenship of immigrants (either Dutch or Bulgarian) and the number of children immigrants have (from one to five), factors which determined the outcome of voters' attitudes. Voters prompted to think of a (culturally close) Dutch individual with one child tended to view them more positively, compared to those who were prompted to think of a (culturally distant) Bulgarian with five children, and thus they were substantially less likely to express chauvinistic sentiments regarding welfare. ${ }^{7}$ A survey experiment of Bay et al. from 2016 analyzed the issue of child allowance and support of Norwegian voters for its potential increase. The results show that a persuasion cue about newly arrived immigrants' access to the social benefits system has only a modest negative impact on the support of the idea of increasing the child allowance. On the other hand, a persuasion cue about labor migrants and their access to benefits (although their children are living in another country) had a very large negative impact (also among respondents who otherwise hold pro-immigrant views) on the support of increased child allowance. ${ }^{8}$

Academic literature dealing with the issue of welfare chauvinism has (so far) focused only on (old) Western and Nordic members of the European Union, and other areas have not been examined yet. This study will analyze attitudes toward cross-border welfare rights from the position of students (the choice of this specific group will be explained later) living in the Czech Republic. The selection of the Czech Republic is not accidental - the country belongs to the group of "new" EU members, Czechs are (despite the fact that immigration in the country is not as high as in Western Europe) generally not supportive of migration into their country and do not see it as beneficial for the society. ${ }^{9}$ For this reason, not only is it interesting to compare the results from

$6 \quad$ W. Van Oorschot, "Making the Difference in Social Europe: Deservingness Perceptions among Citizens of European Welfare States”, Journal of European Social Policy, vol. 16, no. 1 (2006), pp. 23-42.

7 See: F. Hjorth, "Who Benefits? Welfare Chauvinism and National Stereotypes", European Union Politics, vol. 17, no. 1 (2016), pp. 3-24.

8 See: A-H. Bay, H. Finseraas, A.W. Pedersen, "Welfare Nationalism and Popular Support for Raising the Child Allowance: Evidence from a Norwegian Survey Experiment”, Scandinavian Political Studies, vol. 39, no. 4 (2016), pp. 482-494.

9 "ESS 2016", European Social Survey, at <https://www.google.com/url?sa=t\&rct=j\&q=\&esrc=s\&so urce $=$ web $\& c d=1 \& \mathrm{cad}=$ rja\&uact $=8 \& v e d=2$ ahUKEwicvqzxncLgAhUIEVAKHeI7DmMQFjAAeg QIAhAC\&url=https\%3A\%2F\%2Fwww.europeansocialsurvey.org\%2Fdocs\%2Ffindings\%2FESS7_ toplines_issue_7_immigration.pdf\&usg=AOvVaw3raDQ4iv-WofIEeSVdsfvX>. 
countries where positions on immigration issues are significantly different (the older western and Nordic members and the newer central and eastern members), but also to fill the gap that exists in the research field at this moment.

\section{EXPERIMENTAL DESIGN AND DATA}

Through a survey experiment conducted on students living in the Czech Republic (specifically Brno), the main aim of the work is to explore whether welfare chauvinism is present in the Czech Republic, and more specifically, how student preferences for increases in the child benefit (as one aspect of social benefits) change when respondents are reminded about immigrants' access to benefits. The core of the experimental design is taken from two mentioned studies of Hjorth and Bay et al., which focused on Swedish and Norwegian populations. ${ }^{10}$

The questionnaire created for this experiment starts with a question about a possible increase in child allowance. The subjects are reminded that in the Czech Republic, there are 960000 people and thousands of children endangered by poverty. The subjects have two options - they can answer they would support an increase, or be against it. Then they are randomly assigned into two groups and asked the second question. Each group is exposed to a different cue. This cue, following the model presented in Hjort's study ${ }^{11}$, is related to the citizenship of immigrants. In Group A, recipients were exposed to an argument about labor immigrants from Bulgaria whose children stayed in the country of origin, and (even though) those Bulgarians could receive child allowance (as EU law admits this option and it has been heavily discussed recently). In Group B, recipients were exposed to the same argument, but instead of Bulgarians, German immigrants are mentioned (the exact questions from all the survey questions are in the appendix). Based on the answer to the first question, the subjects who initially supported the idea of increasing child allowance are asked if they would nonetheless support an increase in the child benefit, and those who initially opposed the idea of increasing child allowance were asked if they would support an increase in the child benefit if eligibility was restricted to children of Czech citizens. This is the moment when the persuasive argument should change the subject's original attitude regarding the increase in child allowance.

The logic behind the choice of these two countries is fairly similar to that of Hjort's study from 2016 - Germany is geographically close and has a common history with the Czech Republic. To the contrary, Bulgaria is a geographically distant country with no major links, apart from the reference to Slavic language, to the Czech Republic (in comparison to Germany). The questions were formed so to be as believable as possible. This means that the chosen countries had to have a certain number of actual immigrants living in the Czech Republic. From all the foreign citizens (in 2017), Germany

10 See: A-H. Bay, H. Finseraas, A.W. Pedersen, "Welfare Nationalism...”, pp. 482-494; F. Hjorth, "Who Benefits?..., pp. 3-24.

11 See: F. Hjorth, "Who Benefits?..." 
$\left(4^{\text {th }}\right.$ place in the rank of foreign countries with the most citizens registered in the Czech Republic) and Bulgaria ( $6^{\text {th }}$ place), were the highest ranking member states from the western EU (Germany) and the eastern EU (Bulgaria). ${ }^{12}$

The descriptive analysis of the results used in this text works with the idea that if a change in preference were to emerge, the persuasive power of argument (and more generally welfare chauvinism) would be present. Furthermore, by creating a randomized survey experiment with two exact groups (apart from the differing citizenship cues), the analysis also allows comparing the two countries and how they are perceived by the Czech students.

The experiment was conducted on students of Masaryk University in Brno. Students represent a very specific segment of society and results from this study could provide interesting findings about their attitudes regarding welfare chauvinism. Also, with my access to all the closed Facebook groups related to Masaryk University and its faculties, I had the opportunity to target more people from this group. All in all, 700 students of Masaryk University were contacted directly (through messages), and more than 12000 indirectly (through posts on the Facebook walls). In total 201 answers were received (102 from Group A, 99 from Group B).

\section{RESULTS, DISCUSSION AND CONCLUSION}

As a result of the randomization of treatment, there were no major differences between the two groups in terms of sex, age, faculty, citizenship, or foreign experiences (whether the respondent had taken part in the Erasmus+ programme), which means that differences in results were mainly caused by the cue regarding the immigrants' citizenship. The analysis of the results delivered two major findings (the full report is included in the appendix).

First, a change in the attitudes was observed. The respondents tend to change their initial opinion more often when they were exposed to the Bulgarian persuasive argument rather than the German persuasive argument. As Figure 1 shows (Figure 2 analyses only Czech students), students that initially support an increase in child allowance decided not to change their opinion and continue to support an increase in child allowance in $68.2 \%$ (66.7\% when only Czech students are involved) of all cases in Group A, in comparison to $72.3 \%$ (67.3\% when only Czech students are involved) in Group B. Different results can be observed among those respondents, who were initially opposed to the increase in child allowance. In Group A, $16.7 \%$ of all students (16.1\% of Czech students) would change their mind and start supporting the benefit increase if the allowance increase were to exclude Bulgarian immigrants (with their children living in Bulgaria) and be restricted only to children of Czech parents. When changing the cue to German immigrants (with their children living in Germany), only $11.8 \%$ (6.9\% (!) of Czech students) would change their initial opinion and start to support an increase of welfare benefits.

12 “Cizinci v ČR 2017”, Czech statistical office, at <https://www.czso.cz/documents/11292/27914491/ 1712_c01t01.pdf/ff9e9fee-08d3-4bdc-a11b-d0ccle3ac184?version=1.0>. 
Figure 1. Results from survey experiment. Distribution of responses to a proposal to increase the child allowance (including other nationalities).

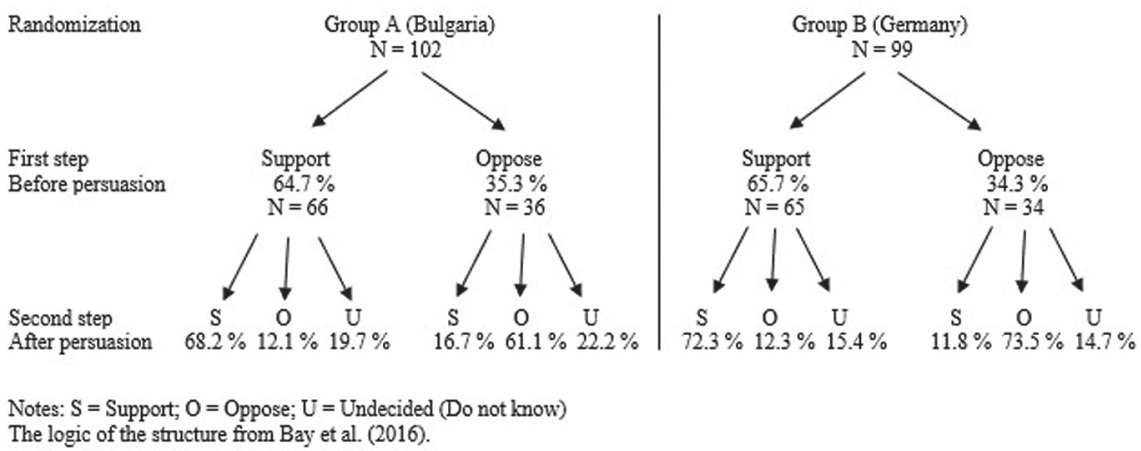

Figure 2. Results from survey experiment. Distribution of responses to a proposal to increase the child allowance (only Czech students).

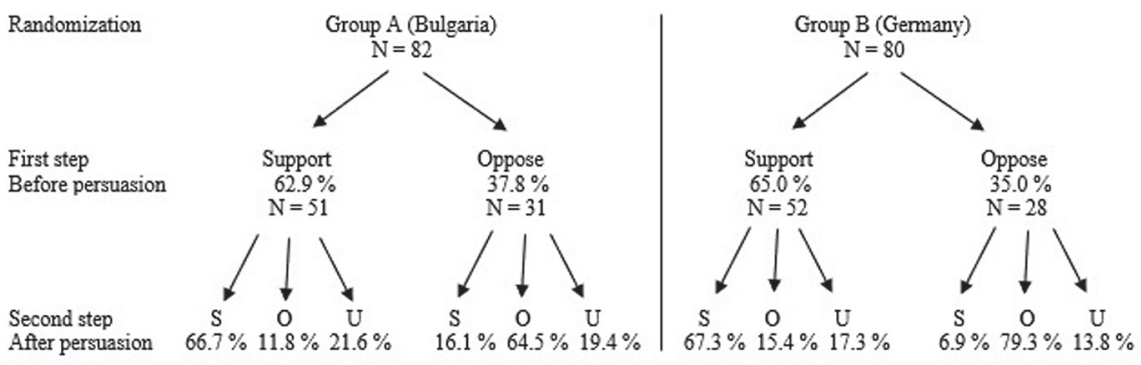

Notes: $\mathrm{S}=$ Support; $\mathrm{O}=$ Oppose; $\mathrm{U}=$ Undecided (Do not know)

The logic of the structure from Bay et al. (2016).

To put it more clearly, Figure 3 (analysing all the respondents) and Figure 4 (analysing only Czech students) are presented. The arrows next to the bars show the effect of the persuasive argument. The longer the arrow, the stronger the persuasive argument in the survey. It shows very clearly that references to the benefit access of Bulgarian labour migrants with children living outside of the Czech Republic has stronger persuasive power than references to the benefit access of German labour migrants. As indicated by the vertical arrows, a total of $34.3 \%$ of the respondents in Group A changed their views on the child allowance as a result of the immigrant persuasive treatment in comparison to $27.3 \%$ of respondents in Group B. The results in Figure 4 could be even more valuable, because Czech students can be portrayed as "true natives" living in their own country. Figure 4 shows that $34.1 \%$ of respondents in Group A changed their initial decision, in comparison to $29 \%$ of those in Group B. This could imply that Czechs perceive Germans more positively than they do Bulgarians, and they behave less chauvinistically towards Germans than citizens from this Eastern European country. 
Figure 3. The distribution of response patterns in the two experimental groups (including other nationalities).

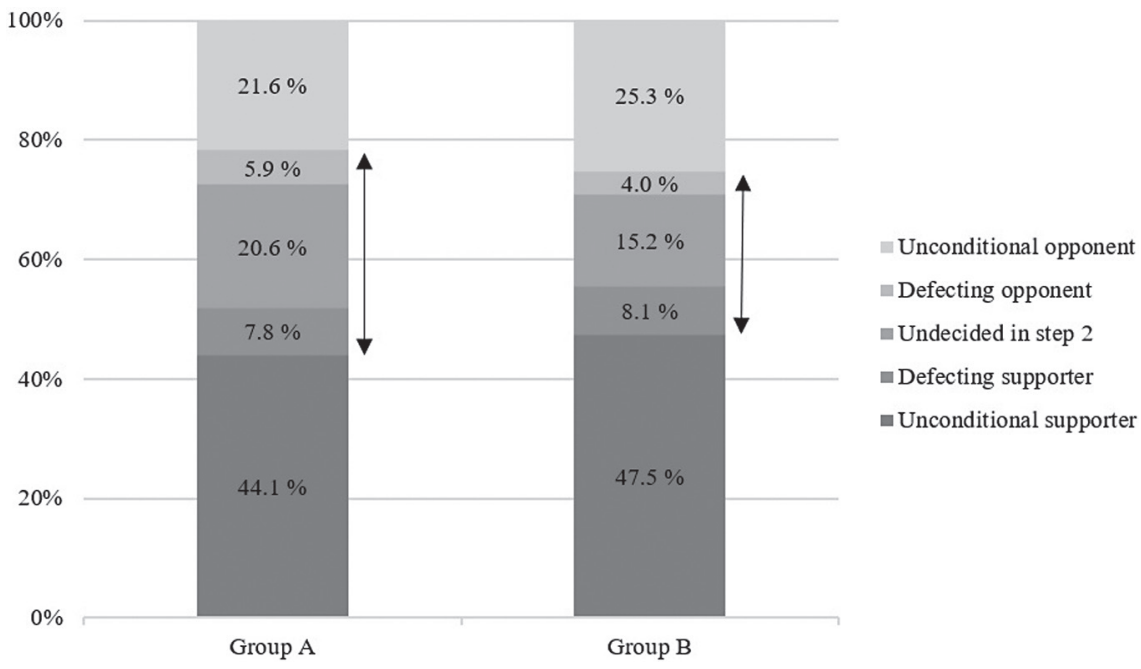

Notes: Unconditional supporters are respondents who agree to the proposal of increasing the child allowance both before and after the persuasion stimulus. Unconditional opponents uphold their opposition from the first step even when offered the opportunity to limit the access to benefits, while defecting opponents change towards support in the second step. Defecting supporters withdraw their initial support in the second step and undecided respondents cannot decide whether to continue with their support/opposition or not (same for every other figure in the study).

Figure 4. The distribution of response patterns in the two experimental groups (only Czech students).

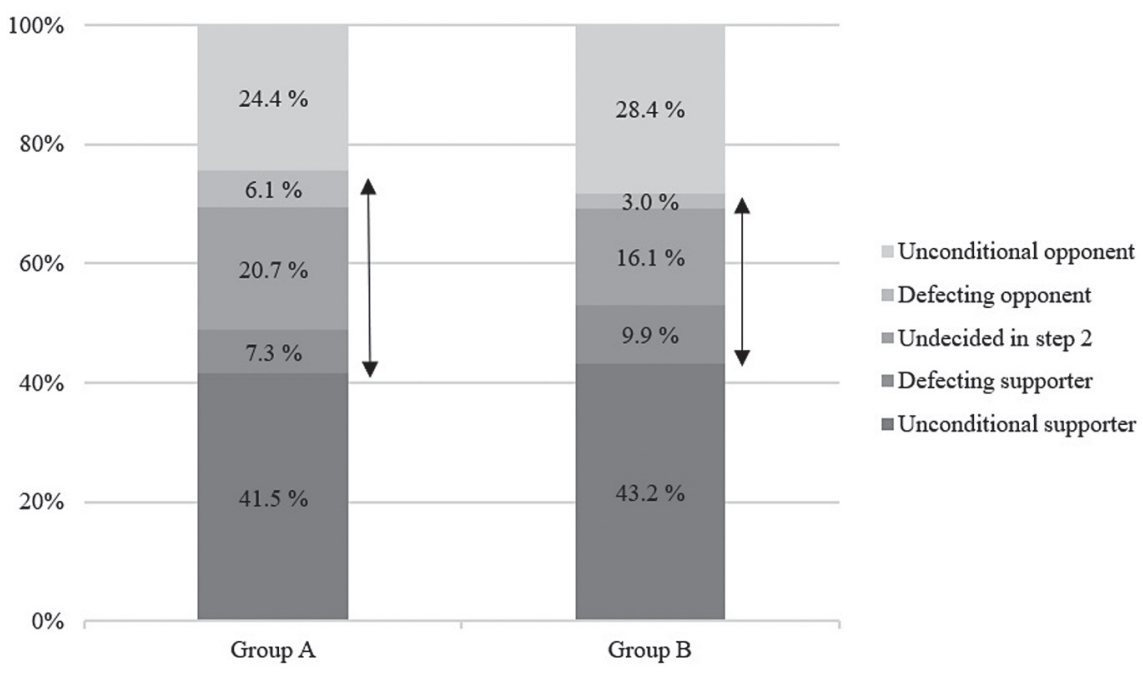


Figure 5. The distribution of response patterns dependent on sex of recipient (only Czech students).

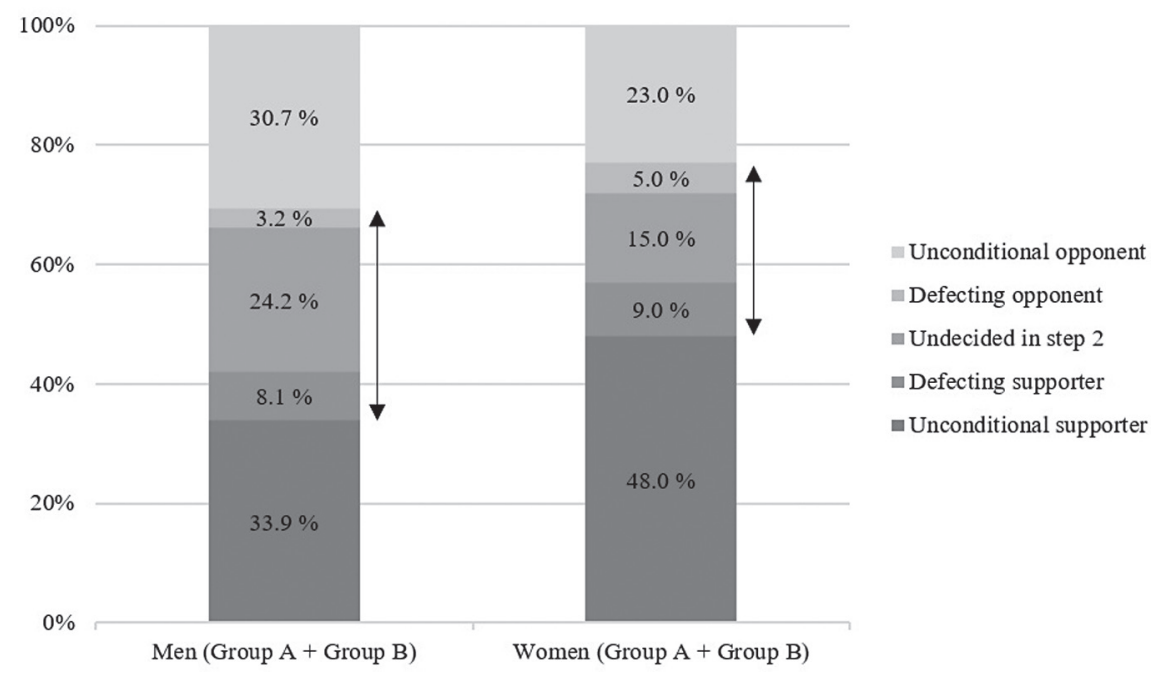

Figure 6. The distribution of response patterns dependent on whether respondent took part in Erasmus + programme (only Czech students).

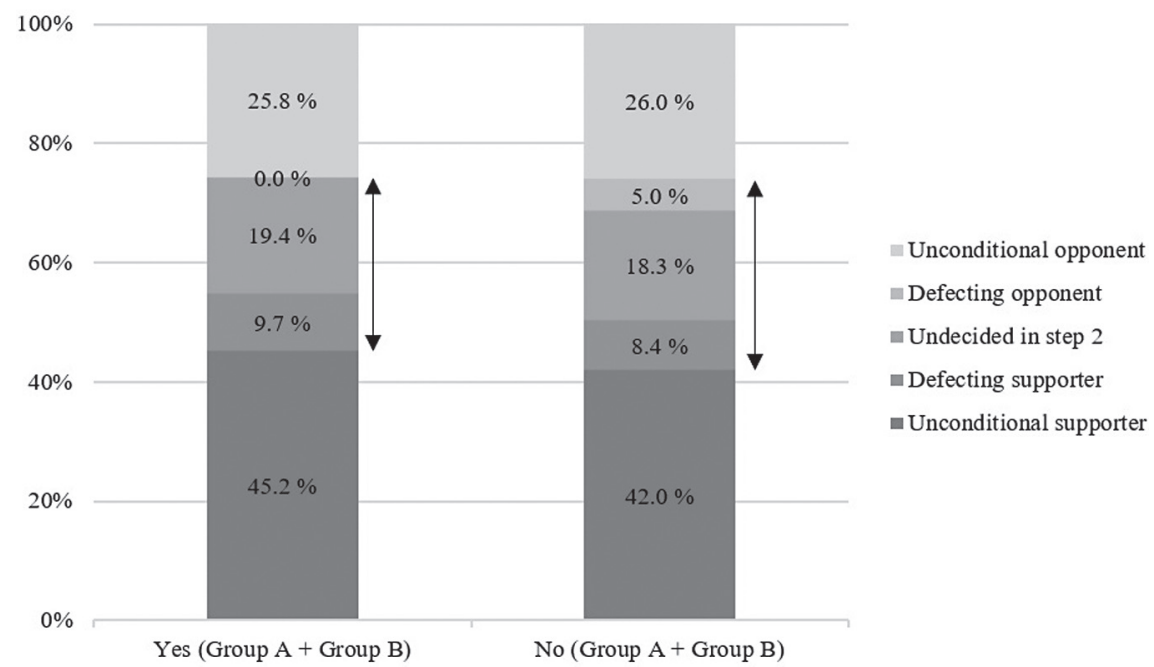

The second set of findings is related to specific characteristics of those students who were more likely to be affected by a persuasive argument. This means these figures did not focus on whether the argument with Bulgarian citizens (Group A) was more persuasive than the argument with German citizens (Group B), but whether men or women in general and students who had participated in the Erasmus+ programme and those who had not participated in the Erasmus+ programme were changing their original 
attitudes more (therefore, Groups A and B were combined). Figure 5 shows that more men (35.5\%) than women (29\%) were affected by treatment and that students who had not taken part in the Erasmus+ programme (31.7\% in comparison to $29.1 \%$ ) more often changed their initial opinions toward an increase in child allowance.

The results of the study indicate that also people from "new" EU member states like the Czech Republic (where the number of immigrants is not as high as in Western Europe) are prone to showing welfare chauvinism. This can provide valuable information for further research and can have implications in real life politics, mostly in political strategy (when there is support for welfare chauvinism, politicians could use this mechanism to gain more popular support).

On the other hand, this experimental research carries its own disadvantages - not only in the way that the experiment was conducted (which has its own flaws), but also that only one segment of society was studied, that of students. Most importantly, the number of respondents (201) cannot compete with more robust studies that are focusing on this issue. Nevertheless, the aim was not to challenge these kinds of studies, but more importantly to open discourse on the issue of welfare chauvinism in a new country like the Czech Republic, with possible future replications or approaches.

\section{BIBLIOGRAPHY}

Alesina A., Glaeser E., Fighting Poverty in the US and Europe: A World of Difference, New York 2004.

Bay A-H., Finseraas H., Pedersen A.W., "Welfare Nationalism and Popular Support for Raising the Child Allowance: Evidence from a Norwegian Survey Experiment", Scandinavian Political Studies, vol. 39, no. 4 (2016), https://doi.org/10.1111/1467-9477.12067.

Citrin J., Green D-P., Muste C., Wong C., "Public Opinion toward Immigration Reform: The Role of Economic Motivations", The Journal of Politics, vol. 59, no. 3 (1997), https://doi. org/10.2307/2998640.

“Cizinci v ČR 2017”, Czech statistical office, at <https://www.czso.cz/documents/11292/ 27914491/1712_c01t01.pdf/ff9e9fee-08d3-4bdc-a11b-d0cc1e3ac184?version=1.0>, 27 December 2019.

De Koster W., Achterberg P., Van der Waal J., “The New Right and the Welfare State: The Electoral Relevance of Welfare Chauvinism and Welfare Populism in the Netherlands", International Political Science Review, vol. 34, no. 1 (2012), https://doi.org/10.1177/ 0192512112455443.

"ESS 2016", European Social Survey. at <https://www.google.com/url?sa=t\&rct=j\&q=\&esrc= s\&source $=$ web \&cd $=1 \& \mathrm{cad}=\mathrm{rja} \&$ uact $=8 \& \mathrm{ved}=2 \mathrm{ahUKEwicvqzxncLgAhUIEVAK}$ HeI7DmMQFjAAegQIAhAC\&url=https\%3A\%2F\%2Fwww.europeansocialsurvey. org\%2Fdocs\%2Ffindings\%2FESS7_toplines_issue_7_immigration.pdf\&usg=AOvVaw3 raDQ4iv-WofIEeSVdsfvX>, 27 December 2019.

Hjorth F., "Who Benefits? Welfare Chauvinism and National Stereotypes", European Union Politics, vol. 17, no. 1 (2016), https://doi.org/10.1177/1465116515607371. 
Kitschelt H., The Radical Right in Western Europe: A Comparative Analysis, Ann Arbor 1997. Kitschelt H., "Growth and Persistence of the Radical Right in Postindustrial Democracies:

Advances and Challenges in Comparative Research", West European Politics, vol. 30, no. 5 (2007), https://doi.org/10.1080/01402380701617563.

Van Oorschot W., "Making the Difference in Social Europe: Deservingness Perceptions among Citizens of European Welfare States", Journal of European Social Policy, vol. 16, no. 1 (2006), https://doi.org/10.1177/0958928706059829.

\section{APPENDIX}

\section{The experiment}

In the first step, respondents are asked a question tapping the support for increases in the child benefit: V České republice bylo vloni ohroženo př́ijmovou chudobou přes 960000 lidí, z toho desítky tisíc detí. Tenhle fakt vedl $\mathrm{k}$ debatě o tom, jestli by rodičovský př́spěvek neměl být zvýšen. Jaký je Váš pohled na návrh zvýšit rodičovský př́spěvek? Měl by se př́spěvek zvýšit? Ano, Ne (In the Czech Republic, there were more than 960000 people threatened by poverty last year, with tens of thousands of children included. This fact has led to a discussion on whether support for the child benefit should be increased. What is your view on a proposal to increase the child benefit? Should the child benefit increase? Yes, No).

In the second step the respondents are randomized into two groups, group $\mathrm{A}$ and group $B$, where the question wording depends on the answer to the question in the first step. Those supporting an increase are randomized to groups A1 and B1, while those opposing the increase are randomized to groups $\mathrm{A} 2$ and $\mathrm{B} 2$ :

\section{A1/B1}

Dnes mají občané z Bulharska/Německa, kteří dojiždějí za prací do Česka stejné právo na rodičovský př́spěvek jako čeští občané, i když jejich děti žijív Bulharsku. I navzdory tomu stále podporujete zvýšení rodičovského př́spěvku? Ano, Ne, Nevím (Today, citizens from Bulgaria/Germany that might have settled in the Czech Republic have the same right to the child benefit as Czech citizens, even if their children live in Bulgaria/Germany. Do you nonetheless support an increase in the child benefit? Yes, No, Don't know).

\section{A2/B2}

Dnes mají občané z Bulharska/Německa, kteří dojiždějí za prací do Česka stejné právo na rodičovský př́spěvek jako čeští občané, i když jejich děti žijív Bulharsku. Podpořili byste zvýšení rodičovského př́spěvku, kdyby se nárok na zvýšení týkal jenom dětí českých rodičủ? Ano, Ne, Nevím (Today, citizens from Bulgaria/Germany who might have settled in the Czech Republic have the same right to the child benefit as Czech citizens, even if their children live in Bulgaria/Germany. Would you support an increase in the child benefit if eligibility was restricted to children of Czech citizens? Yes, No, Don't know). 


\section{Results from the experiment}

Figures 1 and 2. Results from both groups A and B, when asked about support for increasing child allowance (before persuasion)

Should the child benefit increase? (Group A) Should the child benefit increase? (Group B)
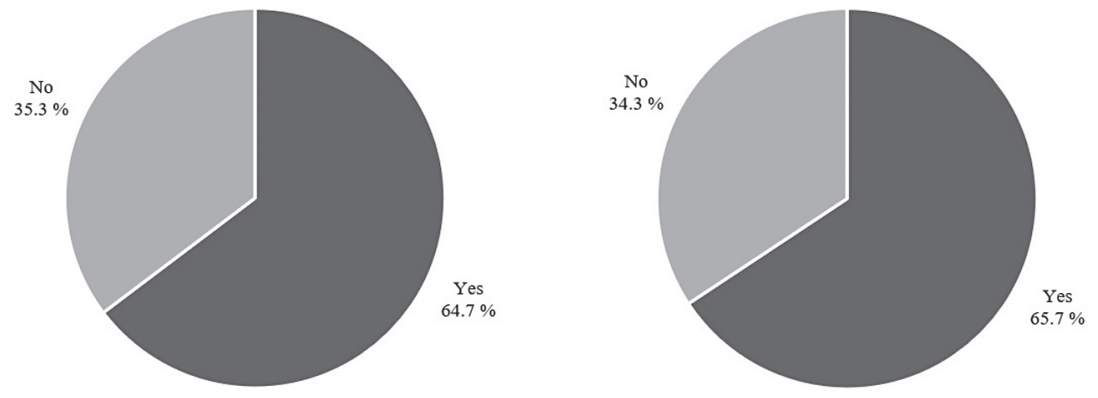

Figures 3 and 4. Reaction of those respondents in group A and B, who answered YES to the first question

Do you nonetheless support an increase in the child benefit?

(Group A)

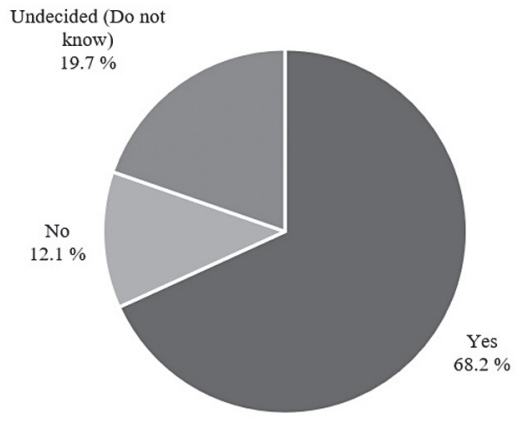

Do you nonetheless support an increase in the child benefit? (Group B)

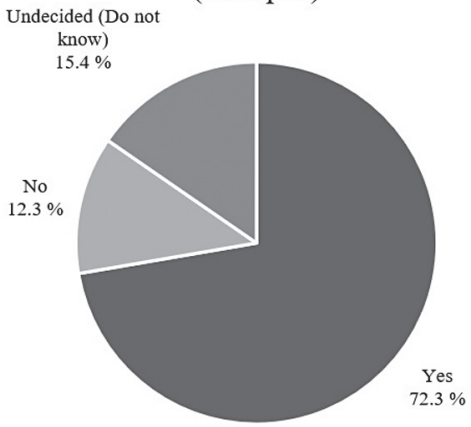


Figure 5. and 6. Reaction of those respondents in group A and B, who answered NO in the first question

Would you support an increase in the child benefit if eligibility was restricted to children of Czech citizens?

(Group A)

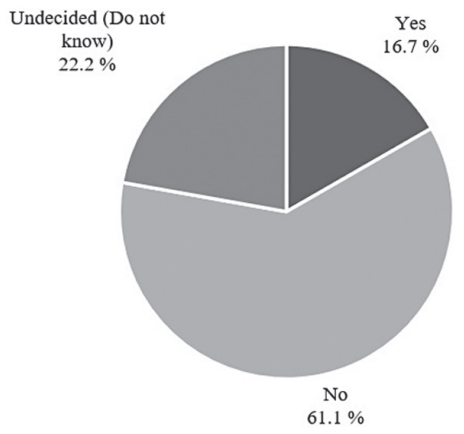

Would you support an increase in the child benefit if eligibility was restricted to children of Czech citizens?

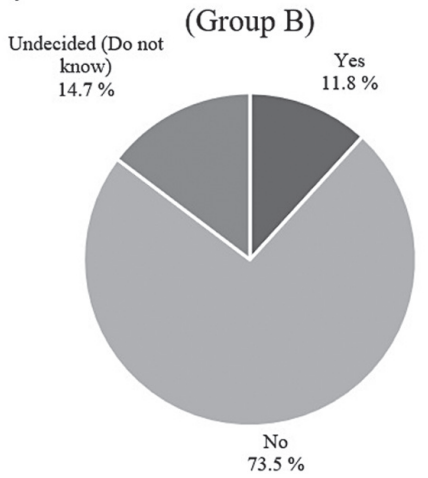

Figures 7 and 8. Comparison of sex in both groups $\mathrm{A}$ and $\mathrm{B}$

Sex (Group A)

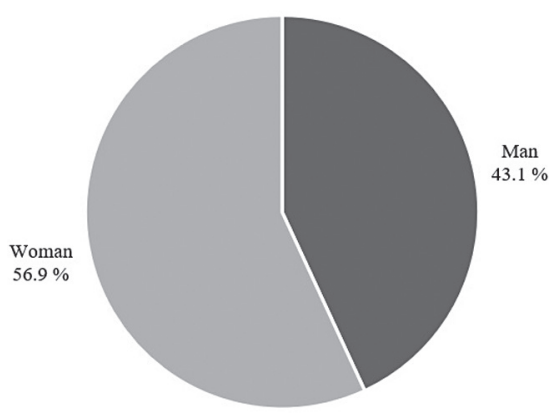

Sex (Group B)

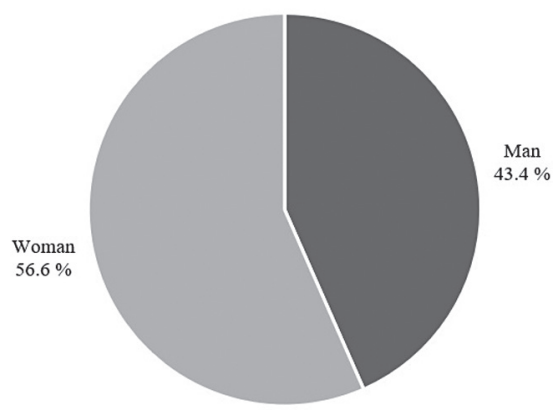


Figures 9 and 10. Comparison of faculties of students in both groups A and B

\title{
Faculty (Group A)
}

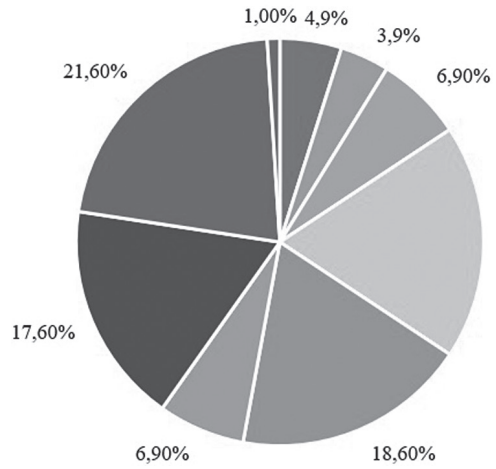

\author{
- Faculty of Law \\ - Faculty of Medicine \\ " Faculty of Science \\ = Faculty of Arts
}

$18,60 \%$

- Faculty of Education

- Faculty of Economics and Administration

- Faculty of Informatics

- Faculty of Social Studies

Faculty (Group B)

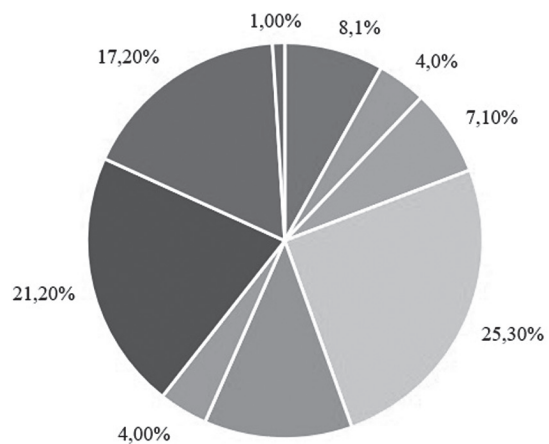
- Faculty of Law
" Faculty of Medicine
" Faculty of Science
= Faculty of Arts
- Faculty of Education
- Faculty of Economics and
Administration
- Faculty of Informatics
- Faculty of Social Studies

Figures 11 and 12. Comparison of state citizenship in both groups A and B

State citizenship (Group A)

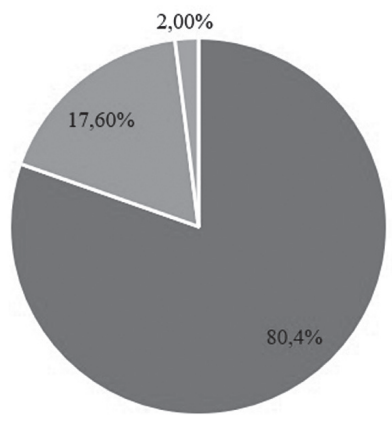

- Czech Republic $\quad$ Slovakia $\quad$ Other
State citizenship (Group B)

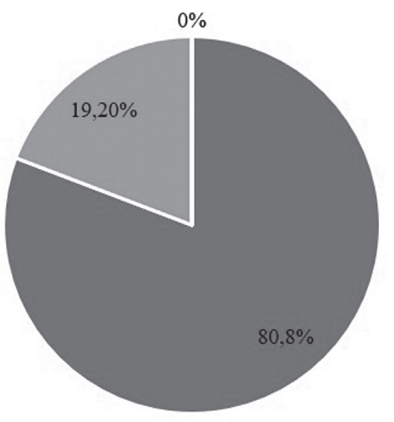

- Czech Republic "Slovakia $=$ Other 
Figures 13 and 14. Comparison of answers, whether respondent took part in Erasmus + programme (in both groups A and B)

Erasmus + experience (Group A)

$$
\text { Erasmus + experience (Group B) }
$$
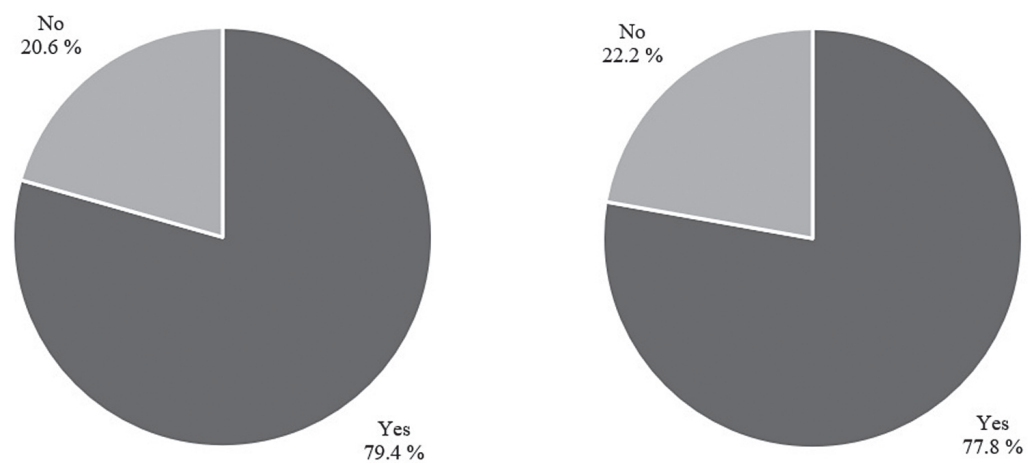

Jakub JUSKO - a master student at the Department of Political Science, Masaryk University in Brno, Czech Republic. He focuses on elections, political psychology and contemporary Slovak and Czech politics. 